DOI: 10.29303/jrpb.v8i1.165

ISSN 2301-8119, e-ISSN 2443-1354

Tersedia online di http://jrpb.unram.ac.id/

\title{
EKSTRAKSI SENYAWA FENOLIK DARI BAWANG PUTIH (Allium sativum L.) UNTUK AGEN ANTI-BIOFOULING PADA MEMBRAN
}

The Extraction of Phenolic Compound from Garlic (Allium sativum L.)

for Anti-Biofouling Agent in Membrane

\section{Yusuf Wibisono*), Ni’matul Izza, Dian Savitri, Shinta Rosalia Dewi, Angky Wahyu Putranto}

Teknik Bioproses, Fakultas Teknologi Pertanian, Universitas Brawijaya

Jl. Veteran, Malang 65145, Indonesia

Email $^{*}$ : Y_Wibisono@ub.ac.id

Diterima: Desember 2019

Disetujui: Maret 2020

\begin{abstract}
Garlic contains several substances that are beneficial, one of which is the phenolic compound. The phenolic compound in garlic has an important role as antibacterial which can be further processed as a membrane anti-biofouling agent. An extraction method such as a sequence procedure of Microwave-Assisted Extraction (MAE) and maceration were used to extract phenolic compounds in garlic. However, the extraction parameters, such as solid to solvent ratio and extraction time need to be considered. Therefore, the aim of this study is to extract the phenolic from garlic with variations of solid to feed ratio $(1: 4,1: 6,1: 8 \mathrm{w} / \mathrm{v})$ and microwave heating time (2, 3, 4 min). The phenolic extracts were quantified by using $U V / V i s$ Spectrophotometer and the data were then analyzed using ANOVA and an LSD test. In addition, the powder extract was also characterized by using FTIR and PSA to determine the functional groups that exist in extracts qualitatively and to measure the size of garlic phenol extracts, respectively. The results showed that the highest total phenolic content (TPC) can be obtained with conditions: solid to solvent ratio of 1:8 (w/v) and extraction time for 2 minutes, which accounted for $9.94 \pm 0.85 \mathrm{mg}$ GAE/g dry extract. FTIR spectra proved that dry extract contains phenolic compounds which are indicated by the presence of $-O-H$ and aromatic groups. In addition, the PSA result showed that the phenolic extract has a particle size of 72.08 $\pm 4.55 \mathrm{~nm}$ which could then be used as a biofouling reducer agent in mixed-matrix membranes.
\end{abstract}

Keywords: garlic, biofouling, phenolic extract, maceration, membrane, microwave-assisted extraction

\begin{abstract}
ABSTRAK
Bawang putih mengandung beberapa zat yang bermanfaat, salah satunya, yaitu senyawa fenolik. Senyawa fenolik pada bawang putih memiliki peranan penting sebagai zat antibakteri yang dapat diproses selanjutnya sebagai anti-biofouling pada membran. Salah satu metode ekstraksi seperti prosedur berurutan berupa Microwave-Assisted Extraction (MAE) dan maserasi digunakan untuk mengekstrak senyawa fenolik pada bawang putih. Namun demikian,
\end{abstract}


parameter ekstraksi, seperti variasi rasio bahan dan pelarut serta lama waktu ekstraksi yang tepat perlu diperhatikan. Oleh karena itu, tujuan penelitian ini adalah mendapatkan ekstrak fenolik dari bawang putih dengan variasi perlakuan rasio bahan dan pelarut $(1: 4,1: 6,1: 8 \mathrm{~b} / \mathrm{v})$ serta lama pemanasan microwave (2, 3, 4 menit). Hasil ekstrak fenolik kemudian dianalisis menggunakan Spektrofotometer UV-Vis dan datanya diolah dengan ANOVA dan uji lanjut BNT. Selain itu, ekstrak padat juga dikarakterisasi dengan FTIR untuk mengetahui gugus fungsi yang ada pada ekstrak secara kualitatif dan PSA untuk mengetahui ukuran ekstrak fenolik bawang putih. Berdasarkan hasil yang diperoleh, total fenolik tertinggi diperoleh pada ekstraksi dengan rasio pelarut 1:8 (b/v) dan waktu pemanasan microwave selama 2 menit, yaitu sebesar 9,94 $\pm 0,85 \mathrm{mg} \mathrm{GAE} / \mathrm{g}$ ekstrak kering. Spektra FTIR membuktikan bahwa ekstrak bawang putih mengandung senyawa fenolik, yang dibuktikan dengan adanya serapan gugus $\mathrm{OH}$ dan serapan senyawa aromatik. Hasil pengukuran PSA menunjukkan bahwa ekstrak bawang putih memiliki ukuran partikel sebesar $72,08 \pm 4,55 \mathrm{~nm}$ yang selanjutnya dapat digunakan sebagai biofouling reducer agent pada membran dengan tipe mixed matrix.

Kata kunci: bawang putih, biofouling, ekstrak fenol, maserasi, membran, microwave-assisted extraction

\section{PENDAHULUAN}

\section{Latar Belakang}

Bawang putih adalah tanaman berumpun dengan ketinggian rata-rata 60 $\mathrm{cm}$ yang banyak dimanfaatkan sebagai bahan makanan. Selain itu, bawang putih juga memiliki kandungan kimia yang bermanfaat sebagai antioksidan. Bawang putih mengandung senyawa allixin, adenosin, ajoene, flavonoid, saponin, tuberholosida, dan scordinin, yang dapat memberikan manfaat untuk kesehatan, seperti anti-hipertensi, anti-trombotik, dan anti-bakteri (Kuswardhani, 2016).

Menurut Hernawan dan Setyawan (2003), bawang putih mengandung senyawa golongan fenol yang dapat berfungsi sebagai zat antibakteri. Fenolik bekerja dengan cara mendenaturasi protein pada bakteri. Fenolik dapat teradsorpsi ke dalam sel bakteri karena mengandung ikatan hidrogen. Jika kadar fenolik rendah, fenolik membentuk protein kompleks dengan ikatan lemah yang akan segera terurai dan diikuti oleh penetrasi fenolik ke dalam sel bakteri, dan menyebabkan presipitasi dan denaturasi protein (Gulfraz, dkk., 2014). Dengan banyaknya manfaat senyawa fenolik, maka banyak tanaman kaya fenolik yang diekstrak untuk dimanfaatkan dalam berbagai sektor, seperti pangan, kosmetik, dan obat-obatan, salah satunya adalah bawang putih.

Pemilihan metode ekstraksi didasarkan pada sifat bahan dan senyawa yang akan diekstrak. Metode yang umum digunakan untuk ektraksi adalah dengan perendaman (maserasi) dan pemanasan pada suhu tinggi. Namun demikian, metode maserasi memerlukan waktu yang relatif lama dan menghasilkan ekstrak yang relatif sedikit, sedangkan metode pemanasan pada suhu tinggi dilaporkan dapat menurunkan yield ekstrak. Hal ini disebabkan karena beberapa senyawa fenolik merupakan senyawa yang tidak tahan panas atau rusak karena panas (termolabil).

Oleh sebab itu, beberapa metode ekstraksi non-thermal seperti ekstraksi menggunakan Pulsed Electric Field (PEF) (Izza, dkk., 2016; Dewi, dkk., 2019), gelombang ultrasonik (Kusrini, dkk., 2018), dan gelombang mikro (microwave) (Izza, dkk., 2018; Putranto, dkk., 2018) dilakukan untuk mengurangi penggunaan suhu tinggi selama proses ekstraksi dan menjadikan total waktu ekstraksi lebih singkat (kurang dari 15 menit) dan menaikkan yield ekstrak yang dihasilkan.

Pada penelitian ini dilakukan ekstraksi fenolik dari bawang putih dengan bantuan gelombang mikro atau Microwave Assisted Extraction (MAE). Ekstraksi menggunakan 
microwave dapat mencegah degradasi senyawa termolabil seperti fenolik karena pemanasan microwave melibatkan pemanasan volumetrik dan bersifat selektif, yaitu sistem akan dipanaskan secara menyeluruh dalam seketika waktu (instantenously throughout) dan senyawa target akan menjadi lebih panas dari sistem sehingga mempercepat proses transfer massa senyawa target dari bahan ke pelarut.

Sementara itu, pemanasan konvensional melibatkan proses konduksi dan konveksi sehingga memungkinkan kerusakan senyawa target. Keuntungan lain dari gelombang mikro adalah waktu ekstraksi cepat, konsumsi energi rendah, kebutuhan pelarut sedikit, hasil ekstrak lebih banyak. Selain itu, adanya proses pengadukan selama proses ekstraksi dapat meningkatkan fenomena transfer panas dan massa (Purwanto, dkk., 2010).

Oleh karena itu, untuk meningkatkan hasil ekstraksi, dilakukan kombinasi metode MAE yang dilanjutkan dengan maserasi (perendaman). Produk akhir yang diinginkan berupa ekstrak kering yang selanjutnya diuji kandungan fenoliknya. Karakterisasi ekstrak juga dilakukan dengan pengujian FTIR dan analisis ukuran partikel yang selanjutnya dapat digunakan sebagai zat anti biofouling pada membran mixed matrix. Biofouling adalah masalah yang sering ditemui pada proses membran yang dipergunakan untuk pengolahan bahan pangan. Ekstrak fenolik dari bawang putih ini diharapkan menjadi bahan alami untuk mencegah terjadinya biofouling sehingga dapat meningkatkan kinerja membran.

\section{Tujuan}

Tujuan penelitian ini adalah mendapatkan ekstrak fenolik dari bawang putih menggunakan kombinasi metode ekstraksi MAE dan maserasi dengan variasi perlakuan rasio bahan dan pelarut serta lama waktu MAE.

\section{METODE PENELITIAN}

\begin{abstract}
Alat dan Bahan
Alat yang digunakan pada peneltiian ini adalah microwave (Samsung tipe ME731K), oven vakum (Memmert VO 400), rotary vacuum evaporator (IKA HB 10), Spektrofotometer UV-Vis (Shimadzu tipe MG23H3185), Fourier Transform InfraRed (Shimadzu Tipe 8400S), dan Particle Size Analyzer (DelsaTM Nano, Cordoun). Bahan yang digunakan dalam penelitian ini antara lain: bawang putih lokal kota Malang, pelarut ethanol, dan bahanbahan yang digunakan untuk analisis total fenolik, yaitu asam galat, natrium karbonat $\left(\mathrm{Na}_{2} \mathrm{CO}_{3}\right)$, dan reagen Folin-Ciocalteau dengan kualitas p.a.
\end{abstract}

\section{Ekstraksi Bawang Putih}

Bawang putih yang telah dikupas dan diiris tipis (ketebalan $\pm 2 \mathrm{~mm}$ ) kemudian dioven pada suhu $50^{\circ} \mathrm{C}$ selama 48 jam. Selanjutnya bawang putih kering diblender hingga halus kemudian diayak dengan ayakan 100 mesh hingga menjadi bubuk yang berukuran seragam (minimal 100 mesh). Proses ekstraksi dilakukan terhadap $25 \mathrm{~g}$ serbuk bawang putih dengan variasi rasio bahan dan pelarut etanol 1:4, 1:6, dan 1:8 (b/v), serta variasi waktu pemaparan microwave dengan daya tetap $180 \mathrm{~W}$ selama 2, 3, dan 4 menit. Setelah itu dilakukan perendaman (maserasi) selama 2 x 24 jam sambil sesekali di-gojok.

Setelah proses perendaman, ekstrak dipisahkan dari residunya dan disimpan dalam refrigerator hingga proses selanjutnya. Dilakukan maserasi kembali terhadap residu yang didapatkan dengan rasio pelarut 1:2, 1:3, dan 1:4 (b/v). Setelah 24 jam, rendaman residu disaring kembali dengan kertas saring, kemudian filtrat yang didapatkan disatukan dengan filtrat yang pertama setelah suhunya disamakan. Filtrat diuapkan dengan rotary evaporator dengan suhu $45^{\circ} \mathrm{C}$ dan kecepatan putaran $65 \mathrm{rpm}$. Pasta dari hasil ekstrak dikeringkan dengan oven vakum pada suhu $40^{\circ} \mathrm{C}$ selama dua 
jam. Hasil padatan dari oven kemudian dihancurkan hingga menjadi bubuk.

\section{Uji Total Fenolik}

Prosedur pengujian total fenolik dilakukan sesuai dengan penelitian Izza, dkk., (2018) dan Putranto, dkk, (2018). Penentuan kandungan fenolik dilakukan dengan reagen Folin-Ciocalteau 10\%, larutan $\mathrm{Na}_{2} \mathrm{CO}_{3} \quad 7,5 \%$ dan asam galat sebagai standar. Reaksi yang terjadi berwarna biru yang berarti terdapat kandungan fenolik pada ekstrak bawang putih. Pengukuran kandungan total fenolik menggunakan Spektrofotometer UV-Vis pada panjang gelombang $765 \mathrm{~nm}$. Kurva kalibrasi total fenolik dibuat terlebih dulu dengan menggunakan asam galat, sehingga total fenolik dibaca sebagai $\mathrm{mg}$ gallic acid equivalent (GAE) per gram ekstrak kering. Kandungan fenolik pada ekstrak dihitung dengan Persamaan 1.

$T F=\frac{\mathrm{A}-\mathrm{b}}{\mathrm{a}} \times f p \times \frac{\mathrm{V}}{\mathrm{M}}$.

Keterangan:

$\mathrm{TF} \quad=$ Total fenolik $(\mathrm{mg} / \mathrm{g})$

A $\quad=$ Nilai Absorbansi yang terukur

a $\quad=$ Nilai pada persamaan $\mathrm{y}=\mathrm{ax}+\mathrm{b}$

$\mathrm{b} \quad=$ Nilai pada persamaan $\mathrm{y}=\mathrm{ax}+\mathrm{b}$

$\mathrm{fp} \quad=$ Faktor pengenceran

$\mathrm{V} \quad=$ Volume ekstrak $(\mathrm{mL})$

$\mathrm{M} \quad=$ Massa ekstrak $(\mathrm{g})$

\section{Pengujian FTIR}

Pengujian FTIR dilakukan dengan menggunakan spektrometer FTIR (Fourier Transform Infrared). Spektroskopi FTIR merupakan teknologi spektroskopi menggunakan sinar inframerah yang dilengkapi dengan transformasi Fourier untuk analisis hasil spektrumnya. Uji FTIR bertujuan untuk mengetahui gugus fungsi yang terdapat pada sampel. Pada penelitian ini, uji FTIR hanya dilakukan pada sampel dengan kandungan total fenolik tertinggi.

\section{Pengujian Ukuran Partikel}

PSA digunakan untuk menentukan ukuran rata-rata suatu partikel. PSA (Particle Size Analyzer) menggunakan metode Dynamic Light Scattering (DLS) yang memanfaatkan hamburan inframerah. Hamburan inframerah ditembakkan oleh alat terhadap sampel sehingga sampel akan bereaksi menghasilkan gerak acak Brown. Gerak inilah yang kemudian dianalisis oleh alat, semakin kecil ukuran molekul maka akan semakin cepat gerakannya.

Pada pengujian sampel ekstraksi bawang putih ini, pengujian PSA dilakukan dengan menggunakan metode basah dimana metode ini menggunakan media pendispersi untuk mendispersikan material uji sehingga partikel tidak saling menggumpal. Dengan demikian ukuran partikel yang terukur adalah ukuran dari partikel tunggal (Mufid, 2016).

\section{Analisis Data}

Data dari parameter pengamatan yaitu total fenolik dianalisis menggunakan analisis sidik seragam atau ANOVA (Analysis of Variance) dan dilanjutkan dengan uji DMRT (Duncan's Multiple Range Test) jika terdapat interaksi antara kedua faktor atau menggunakan uji BNT (Beda Nyata Terkecil) jika tidak terdapat interaksi antara kedua faktor. Penentuan perlakuan terbaik ditentukan berdasarkan total fenolik tertinggi dari sampel.

\section{HASIL DAN PEMBAHASAN}

\section{Rendemen Ekstraksi Bawang Putih}

Pemaparan gelombang mikro dengan variasi waktu 2, 3, dan 4 menit pada saat proses ekstraksi mengakibatkan hasil suhu akhir ekstrak yang berbeda-beda. Perbedaan suhu pada masing-masing pelakuan dapat dilihat pada Gambar 1. Berdasarkan Gambar 1 tersebut, dapat dilihat bahwa hubungan antara waktu MAE dan suhu adalah berbanding lurus. Peningkatan suhu terjadi karena semakin lama waktu ekstraksi, maka semakin banyak energi elektromagnetik yang dirubah menjadi energi panas. 


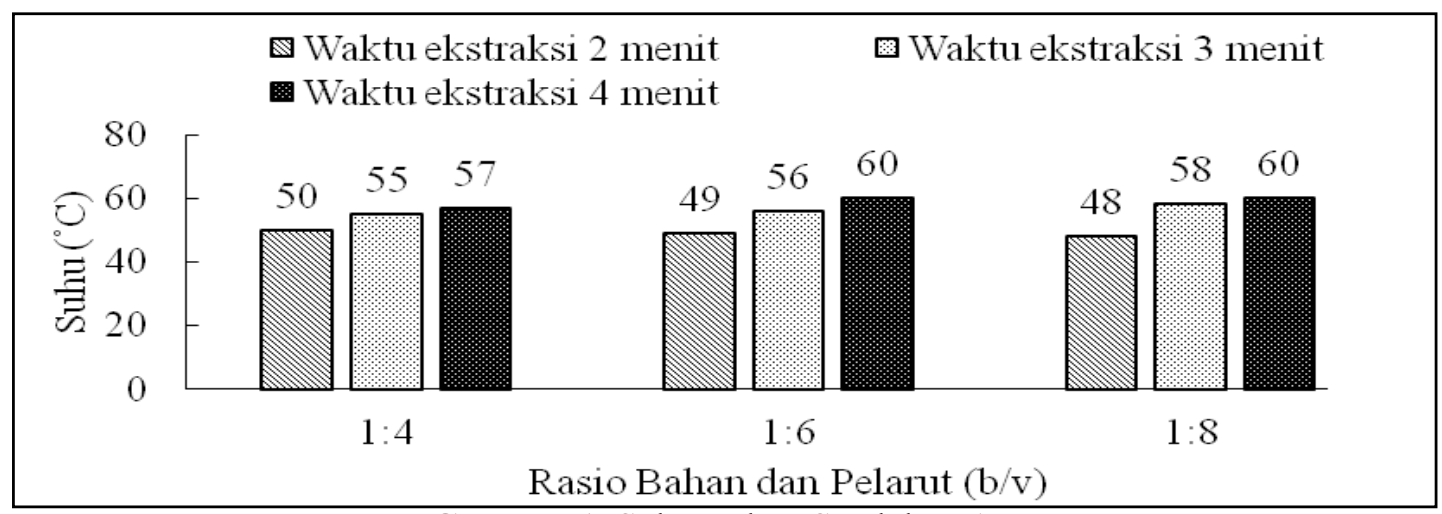

Gambar 1. Suhu Bahan Setelah MAE

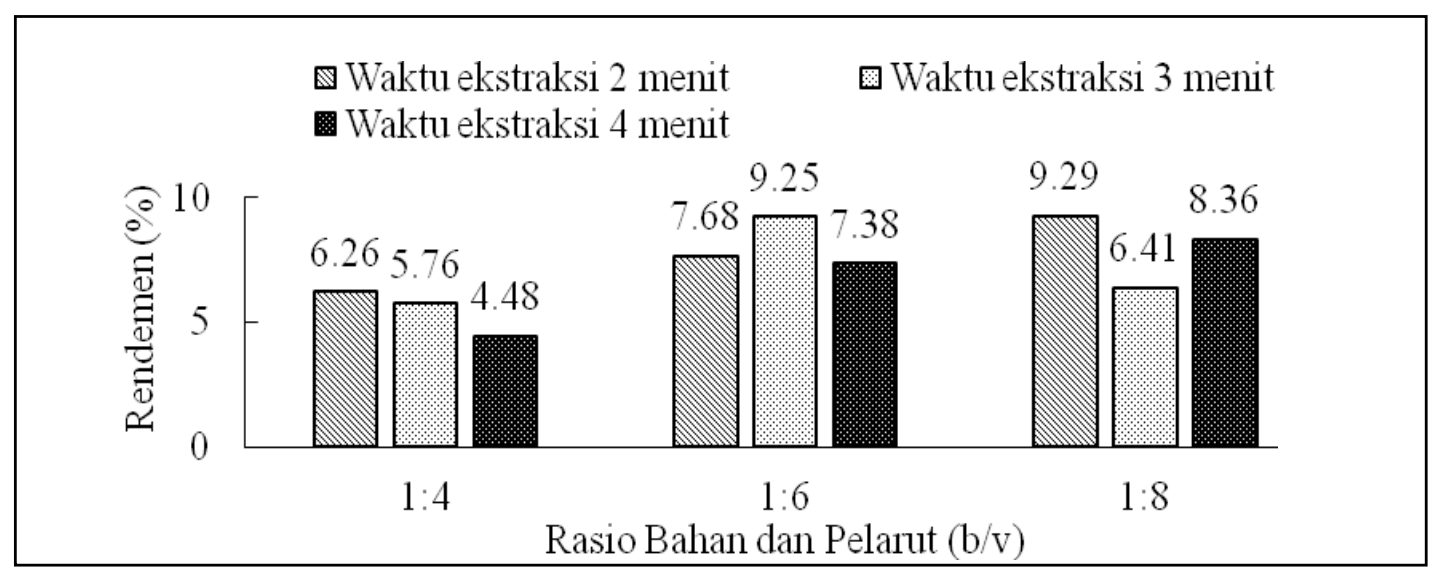

Gambar 2. Rendemen Ekstrak Kering Bawang Putih

Temperatur yang lebih tinggi dapat dicapai oleh dinding sel selama MAE sehingga dapat mengurangi kekuatan mekanik serta membantu pelarut untuk mudah masuk mengekstraksi senyawa di dalam sel (Meidayanti dkk, 2015).

Selain suhu, nilai rendemen ekstrak kering juga dihitung. Grafik rerata hasil nilai rendemen ekstrak kering bawang putih akibat perlakuan rasio pelarut dan lama waktu pemaparan microwave dapat dilihat pada Gambar 2. Hasil rendemen tertinggi pada rasio pelarut 1:8 (b/v) dengan lama waktu ekstraksi 2 menit yaitu 9,95\% dan terendah pada rasio pelarut $1: 4(\mathrm{~b} / \mathrm{v})$ dengan lama waktu ekstraksi 4 menit yaitu 4,48\%. Dari data tersebut terlihat bahwa pada rasio 1:4 dan 1:8 rendemen memiliki kecenderungan naik sedangkan pada rasio 1:6 meningkat pada waktu 3 menit dan turun pada lama MAE 4 menit. Hal ini menunjukkan semakin banyak volume pelarut semakin besar pula hasil rendemennya.
Berdasarkan Gambar 2 juga dapat dilihat bahwa rendemen ekstrak kering hasil ekstraksi dengan microwave dan maserasi berkisar antara 4,48\% - 9,29\%. Nilai rendemen tertinggi pada penelitian ini sudah lebih baik dibandingkan dengan penelitian Yuswi (2017) yang mengekstrak fenolik dari bawang dayak dengan metode ultrasonik bath dengan hasil rendemen ekstrak tertinggi sebesar 7.84\% (ekstrak cair) (Yuswi, 2017). Hal ini membuktikan bahwa kombinasi metode ekstraksi microwave dan maserasi menunjukkan performansi yang lebih baik dari pada metode ultrasonik bath.

\section{Penentuan Kandungan Fenolik Total}

Kandungan fenolik total pada masingmasing ekstrak dinyatakan sebagai ekuivalen asam galat atau Gallic Acid Equivalent (GAE) per gram ekstrak kering. GAE merupakan acuan umum untuk mengukur sejumlah senyawa fenolik yang 
Tabel 1. Hasil Rata-Rata Total Fenol Ekstrak Kering Bawang Putih (mg GAE/g ekstrak kering)

\begin{tabular}{cccc}
\hline $\begin{array}{c}\text { Rasio Bahan dan } \\
\text { Pelarut (b:v) }\end{array}$ & Waktu MAE 2 menit & Waktu MAE 3 menit & Waktu MAE 4 menit \\
\hline $1: 4$ & $6,47 \pm 0,03$ & $6,21 \pm 0,10$ & $5,81 \pm 0,18$ \\
$1: 6$ & $5,64 \pm 0,74$ & $6,60 \pm 0,19$ & $6,00 \pm 0,14$ \\
$1: 8$ & $9,94 \pm 0,85$ & $8,02 \pm 2,94$ & $8,60 \pm 1,57$ \\
\hline
\end{tabular}

terdapat dalam suatu bahan. Hasil uji menunjukkan ekstrak kering bawang putih mempunyai total fenolik antara 5,64 $\pm 0,74$ sampai dengan 9,94 $\pm 0,85 \mathrm{mg}$ GAE/g ekstrak kering. Hasil rata-rata total fenolik ekstrak kering bawang putih dengan variasi rasio pelarut dan lama waktu MAE selama 2, 3 dan 4 menit dapat dilihat pada Tabel 1.

Berdasarkan Tabel 1, dapat dilihat bahwa meskipun pada perlakuan waktu MAE 2 menit ada sedikit penurunan total fenolik pada rasio 1:6, namun secara umum nilai total fenolik cenderung naik dengan semakin banyaknya pelarut yang digunakan, baik dengan waktu MAE 2, 3, maupun 4 menit. Dari trend data tersebut, dapat disimpulkan bahwa semakin banyak pelarut yang digunakan dapat meningkatkan penetrasi pelarut ke dalam dinding sel bahan sehingga senyawa fenol dapat lebih banyak dilepaskan dan larut ke dalam pelarut. Selain itu, semakin banyak pelarut, maka tingkat kejenuhan pelarut pada saat proses ekstraksi menjadi lebih rendah; hal ini dapat meningkatkan laju perpindahan fenolik dari bahan ke pelarut. Selain itu, lamanya paparan microwave dapat meningkatkan kandungan fenolik yang terekstrak karena pemanasan microwave terjadi secara volumetrik dan bersifat selektif (selective heating) (Galan, dkk., 2017).

Pada pemanasan volumetrik, sistem akan dipanaskan secara seketika waktu (instantaneously throughout) sehingga pemanasan menjadi lebih cepat. Sementara adanya pemanasan selektif (selective heating), senyawa fenolik akan dipanaskan lebih cepat dari sistem sehingga menghasilkan gradien suhu yang dapat merusak sel bahan, akibatnya senyawa fenolik akan keluar dari bahan dan terlarut dalam pelarutnya. Oleh sebab itu, semakin lama waktu MAE, semakin banyak fenolik yang terekstrak ke dalam pelarut. Kemudian, penggunaan etanol sebagai pelarut pada ekstraksi dengan MAE dapat meningkatkan efektivitas ekstraksi karena etanol merupakan senyawa polar dan mempunyai nilai loss tangent sebesar 0.941 (Galan, dkk., 2017) sehingga sangat baik dalam menyerap energi microwave dan mengubahnya menjadi energi panas.

Lebih lanjut, penggunaan pelarut yang lebih banyak dapat meningkatkan konduktivitas larutan sehingga efek panas dari microwave dapat lebih optimal membantu proses perusakan dinding sel dan pelepasan senyawa fenolik. Hal ini sejalan dengan hasil penelitian Izza, dkk., (2018) dimana total fenolik tertinggi pada ekstrak biji kelor dengan ekstraksi MAE didapatkan dengan jumlah pelarut paling besar, yaitu dengan rasio bahan dan pelarut 1:8. Hasil penelitian Manasika \& Widjanarko (2015) pada ekstraksi labu kaboca semakin banyak pelarut yang digunakan, semakin banyak senyawa yang terekstrak, sehingga terjadi peningkatan kadar total fenolik (Manasika \& Widjanarko, 2015). Semakin lama ekstraksi maka akan memberikan kesempatan kontak antara bahan dengan pelarut semakin besar, sehingga komponen dalam larutan akan meningkat hingga mencapai titik jenuh (Wuryantoro \& Susanto, 2014). Hasil analisis sidik ragam (ANOVA), menunjukkan bahwa rasio bahan dan pelarut memberikan pengaruh nyata terhadap nilai total fenolik ekstrak kering bawang putih, sehingga dilanjutkan dengan uji beda nyata terkecil (BNT) $\alpha=$ 0,05 seperti yang ditunjukkan pada Tabel 2 .

Berdasarkan hasil uji lanjut BNT didapatkan bahwa variasi rasio 1:4 dan 1:6 tidak berbeda nyata, yang berbeda nyata hanya untuk variasi 1:8 dengan signifikasi $\alpha$ $=0,05$. Hal ini menyatakan bahwa rasio 
Tabel 2. Uji BNT Pengaruh Rasio Pelarut Terhadap Total Fenol

\begin{tabular}{cccc}
\hline $\begin{array}{c}\text { Rasio Bahan dan Pelarut } \\
\text { (b:v) }\end{array}$ & $\begin{array}{c}\text { Rerata Total Fenol } \\
\text { (mg GAE/g DW ekstrak) }\end{array}$ & Notasi & $\begin{array}{c}\text { BNT } \\
\alpha=0,05\end{array}$ \\
\hline $1: 4$ & $6,16 \pm 0,33$ & a & 0,898 \\
$1: 6$ & $6,08 \pm 0,49$ & a & 0,898 \\
$1: 8$ & $8,85 \pm 0,98$ & b & 0,001 \\
\hline
\end{tabular}

Tabel 3. Bilangan Gelombang Dan Gugus Fungsi Ekstrak Bawang Putih

\begin{tabular}{cccc}
\hline $\begin{array}{c}\text { Bilangan Gelombang } \\
\text { Representatif }\left(\mathrm{cm}^{-1}\right)\end{array}$ & $\begin{array}{c}\text { Gerakan } \\
\text { Molekul }\end{array}$ & Bilangan Gelombang $\left(\mathrm{cm}^{-1}\right)$ & Gugus Fungsi \\
\hline $3600-3200$ & Kuat & 3334,69 & O-H \\
$3000-2800$ & Kuat & 2995,53 & C-H \\
$1800-1560$ & Kuat & 1629,74 & $\mathrm{C}=\mathrm{O} / \mathrm{C}=\mathrm{C}$ \\
$1440-1260$ & Kuat & 1400,22 & O-H \\
$1260-960$ & Kuat & 1053,06 & C-O \\
\hline
\end{tabular}

bahan dan pelarut sebesar 1:8 (b/v) pada ekstraksi senyawa fenolik bawang putih menggunakan MAE dapat mengekstrak senyawa fenol lebih baik dengan total fenolik ekstrak lebih besar jika dibandingkan dengan menggunakan rasio bahan dan pelarut 1:4 atau 1:6. Semakin banyak pelarut yang digunakan, maka senyawa fenolik akan mudah dilarutkan dalam pelarut selama proses pemecahan sel menggunakan gelombang mikro. Namun demikian perlu dilakukan penelitian lanjutan untuk menambah jumlah pelarut (lebih dari 1:8) agar senyawa fenolik yang dapat diekstrak menjadi lebih maksimal. Hasil analisis sidik ragam untuk variasi waktu ekstraksi MAE terhadap nilai total fenol ekstrak kering bawang putih pada penelitian ini menunjukkan hasil yang tidak berbeda nyata dengan $\alpha=0,05$.

\section{Hasil Pengujian FTIR}

Uji FTIR ekstrak kering bawang putih ini dilakukan pada sampel dengan kandungan fenol paling tinggi yaitu perlakuan rasio 1:8 dengan lama waktu ekstraksi 2 menit. Hasil analisis pengujian FTIR dapat dilihat pada Gambar 3. Pada hasil ini, menunjukkan adanya beberapa gugus senyawa yang terdapat pada ekstrak bawang putih antara lain $\mathrm{C}=\mathrm{C}, \mathrm{O}-\mathrm{H}, \mathrm{C}-\mathrm{O}$, dan $\mathrm{C}=\mathrm{O}$ seperti pada Tabel 3. Diketahui bahwa senyawa fenolik merupakan senyawa yang memiliki gugus $\mathrm{O}-\mathrm{H}$ dan beberapa cincin aromatik. Dari analisis spektrofotometri infra merah menunjukan adanya gugus hidroksil pada sampel ekstrak bawang putih.

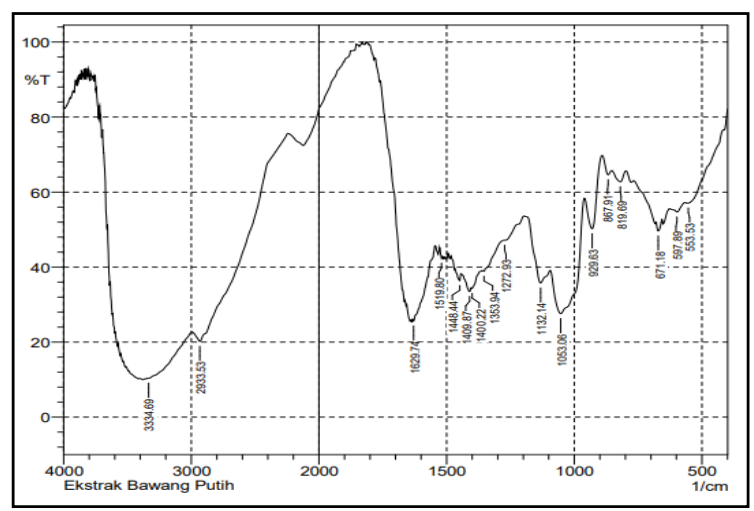

Gambar 3. Hasil Pengujian FTIR Ekstrak Bawang Putih

Senyawa fenolik ditunjukkan dengan adanya puncak spesifik dari gugus $-\mathrm{O}-\mathrm{H}$ di daerah 3334,69 $\mathrm{cm}^{-1}$ dengan intensitas kuat dan melebar, yang didukung oleh serapan pada daerah bilangan gelombang 1400,22 $\mathrm{cm}^{-1}$. Senyawa fenol juga didukung adanya serapan pada daerah sidik jari dengan bilangan gelombang $926,63 \mathrm{~cm}^{-1}$ yang menunjukkan adanya gugus $\mathrm{C}-\mathrm{C}$ dan $\mathrm{C}=\mathrm{C}$ senyawa aromatik. Pada daerah bilangan gelombang 2995,53 cm $\mathrm{cm}^{-1}$ menunjukkan adanya serapan uluran $\mathrm{C}-\mathrm{H}$ aromatik. Karakteristik lain yang mengindikasikan adanya cincin aromatik ditunjukkan adanya serapan pada daerah bilangan gelombang $1629,74 \mathrm{~cm}^{-1}$ yang merupakan serapan dari 
regangan cincin $\mathrm{C}=\mathrm{C}$ aromatik. Kemudian diperkuat dengan adanya serapan pada $1053,06 \mathrm{~cm}^{-1}$ yang merupakan uluran gugus aromatik. Sehingga, ekstrak kering bawang putih dipastikan memiliki kandungan fenolik.

\section{Hasil Uji PSA}

Ekstrak kering bawang putih juga diuji Particle Size Analysis (PSA). Pengujian dilakukan untuk diketahui ukuran partikel karena salah satu manfaat ekstrak kering bawang putih dapat berfungsi sebagai bahan pencegahan biofouling, dengan pengisi (filler) pada membran dengan tipe mixed matrix. Pada pengujiannya terjadi lima kali pengulangan dengan pendistribusian ukuran PSA dengan ratarata ukuran partikel sebesar 72,08 $\pm 4,55$ nm. Hasil pengujian PSA dapat dilihat pada Tabel 4.

Tabel 4. Hasil Pngujian Ukuran Partikel Ekstrak Bawang Putih

\begin{tabular}{cccc}
\hline Ulangan & $\begin{array}{c}\text { Ukuran } \\
\text { partikel }(\mathrm{nm})\end{array}$ & $\begin{array}{c}\text { Rerata } \\
(\mathrm{nm})\end{array}$ & Error \\
\hline 1 & 72,52 & & \\
2 & 79,83 & & \\
3 & 69,04 & 72,08 & 4,55 \\
4 & 69,53 & & \\
5 & 69,47 & & \\
\hline
\end{tabular}

Beberapa penelitian menyatakan bahwa terjadi peningkatan ketahanan dan penurunan biaya produksi sel bahan bakar karena adanya penggabungan material filler berukuran kecil atau bahkan sampai berukuran nanometer (Thiam, dkk., 2011). Penggunaan material filler anorganik dengan ukuran yang lebih kecil diketahui dapat meningkatkan performa dan kinerja membran untuk aplikasi sel bahan bakar. Hal ini disebabkan terjadinya peningkatan luas permukaan, daya dan kerapatan energi pada membran yang dihasilkan.

\section{KESIMPULAN DAN SARAN}

Total fenol tertinggi didapatkan pada perlakuan rasio bahan dan pelarut 1:8 dengan lama pemaparan MAE 2 menit yaitu sebesar 9,94 $\pm 0,85 \mathrm{mg}$ GAE/g ekstrak kering dan memiliki rendemen sebesar 9,29\%. Perlakuan rasio bahan dan pelarut yang digunakan selama proses ekstraksi menggunakan MAE memiliki pengaruh yang nyata terhadap nilai total fenol yang dihasilkan. Hasil uji FTIR juga menunjukkan bahwa pada ekstrak kering yang dihasilkan terdapat senyawa fenol yang dibuktikan dengan adanya gugus fungsi alkohol. Selain itu, ekstrak kering bawang putih yang dihasilkan memiliki ukuran partikel sebesar 72,08 $\pm 4,55 \mathrm{~nm}$ yang selanjutnya dapat digunakan sebagai agen pencegahan biofouling pada membran dengan tipe mixed matrix.

\section{UCAPAN TERIMA KASIH}

Penulis mengucapkan terima kasih kepada Kementerian Ristek dan Dikti dan LPPM Universitas Brawijaya yang telah memberikan dukungan pendanaan atas penelitian ini melalui program Penelitian Terapan Unggulan Perguruan Tinggi (PTUPT) Tahun 2019-2021.

\section{DAFTAR REFERENSI}

Dewi, S.R., Sumarni, N., Izza, N., Putranto, A.W., \& Susilo, B. (2019). Studi Variasi Kuat Medan Listrik PEF dan Metode Pengeringan Bahan terhadap Senyawa Antioksidan Ekstrak Daun Torbangun (Coleus amboinicus L.). Jurnal Keteknikan Pertanian, 7(1), 91-98. doi:10.19028/jtep.07.1.91-98.

Galan, A.M., Calinescu, I., Trifan, A., Winkworth-Smith, C., CalvoCarrascal, M., Dodds, C., \& Binner, E. (2017). New insight into the role of selective and volumetric heating during microwave extraction: Investigation of the extraction of polyphenolic compounds from sea buckthorn leaves using microwaveassisted extraction and conventional solvent extraction. Chemical Engineering and Processing, 116, 29- 
39. doi: 10.1016/j.cep.2017.03.006.

Gulfraz, M., Imran, M., Khadam, S., Ahmed, D., Asad, M.J., Abassi, K.S., Irfan, M., \& Mehmood, S. (2014). A comparative study of antimicrobial and antioxidant activities of garlic (Allium sativum L.) extracts in various localities of Pakistan. African Journal of Plant Science, 8(6), 298-306. doi:10.5897/ajps11.252.

Hernawan, U.E., \& Setyawan, A.D. (2003). Review: Organosulphure compound of garlic (Allium sativum L.) and its biological activities. Biofarmasi Journal of Natural Product Biochemistry, 1(2), 65-76. doi:10.13057/biofar/f010205.

Izza, N., Dewi, S.R., Putranto, A. W., \& Yuneri, D. (2016). Extraction of Phenolic Compounds from Cosmos caudatus using Pulse Electric Field (PEF). Jurnal Teknologi Pertanian, 17(2), 91-96. doi:10.21776/ub.jtp.2016.017.02.2.

Izza, N., Dewi, S.R., Setyanda, A., Sukoyo, A., Utoro, P., Al Riza, D.F., \& Wibisono, Y. (2018). Microwaveassisted extraction of phenolic compounds from Moringa oleifera seed as anti-biofouling agents in membrane processes. MATEC Web of Conferences, 204. doi:10.1051/matecconf/20182040300 3.

Kusrini, E., Tristantini, D., \& Izza, N. (2018). Uji Aktivitas Ekstrak Bunga Telang (Clitoria ternatea L.) Sebagai Agen Anti-Katarak. Jurnal Jamu Indonesia, 2(1), 30-36. doi: 10.29244/jji.v2i1.28.

Kuswardhani, D.S. (2016). Sehat Tanpa Obat dengan Bawang Merah dan Bawang Putih. Yogyakarta: Rapha Publishing.
Manasika, A., \& Widjanarko, S.B. (2015). Ekstraksi Pigmen Karotenoid Labu Kabocha menggunakan Metode Ultrasonik (Kajian Rasio Bahan Pelarut dan Lama Ekstraksi). $J$. Pangan dan Agroindustri, 3(3), 928938.

Mufid, Ali. (2016). Sintesis dan Karakterisasi Komposit Lithium Ferro Phosphate/Grafite dengan Variasi Fraksi Berat Grafite Melalui Proses Solid State. Tesis. Institut Teknologi Sepuluh Nopember. Surabaya.

Purwanto, H., Hartati, I., \& Kurniasari, L. (2010). Pengembangan Microwave Assisted Extractor (MAE) pada Produksi Minyak Jahe dengan Kadar Zingiberene Tinggi. Momentum, 916.

Putranto, A.W., Dewi, S.R., Izza, N., Yuneri, D.R., Dachi, M.Y.S., \& Sumarlan, S.H. (2018). Ekstraksi senyawa fenolik daun kenikir (Cosmos caudatus) menggunakan Microwave Assisted Extraction (MAE). Rona Teknik Pertanian, 11(1), 60-71.

Putri, N.K.M., Gunawan, I.W.G, \& Suarsa, I.W. (2015). Aktivitas Antioksidan Antosianin dalam Ekstrak Etanol Kulit Buah Naga Super Merah (Hylocereus costaricensis) dan Analisis Kadar Totalnya. Jurnal Kimia, 9(2), 243-251.

Thiam, H.S., Daud, W.R.W., Kamarudin, S.K., Mohammad, A.B., Kadhum, A.A.H., Loh, K.S., \& Majlan, E.H. (2011). Overview on nanostructured membrane in fuel cell applications. International Journal of Hydrogen Energy, 36(4), 3187-3205. doi:10.1016/j.ijhydene.2010.11.062. 
Wuryantoro, H., \& Susanto, W. H. (2014). Penyusunan standard operating procedures industri rumah tangga pangan pemanis alami instan sari stevia (Stevia rebaudiana). Jurnal Pangan dan Agroindustri, 2(3), 7687.
Yuswi, N.C.R. (2017). Ekstraksi Antioksidan Bawang Dayak (Eleutherine Palmifolia) dengan Metode Ultrasonic Bath (Kajian Jenis Pelarut dan Lama Ekstraksi). Jurnal Pangan dan Agroindustri, 5(1), 7178. 